\title{
The Choices of a Group of Chemistry Trainee Teachersusing Thematic Teaching/Learning Materials
}

\author{
Daniela Martins BucciniPena \\ Master's in Education and Ph.D \\ Student in the Graduate Program in Education \\ Faculty of Education \\ Federal University of Minas Gerais \\ Brazil \\ Ana Luiza de Quadros \\ Ph.D. in Education \\ Associate Professor of the Department of Chemistry \\ Institute of Exact Sciences, and of the Graduate Program in Education \\ Faculty of Education \\ Federal University of Minas Gerais \\ Brazil
}

\begin{abstract}
Since social historical psychology has led us to take into account the ideas that students take to the classroom, teacher training courses have been committed to prepare them for this task. This study was conducted in an attempt to choices that the in-training chemistry teachers make when developing classes having a thematic didactic material that associates Science, Technology and Society (STS) assumptions, in particular, teaching based on themes. The weekly meetings and the school classes were filmed and analysed. The classes were very interactive and sometimes dialogic. The teaching/learning materials made it easier the appropriation of some contemporary trends on teaching contributed to the construction of a more reflective practice.
\end{abstract}

Keywords:Teacher training, Communicative approach, context-based teaching, teaching and learning material.

\section{Introduction}

Constructivist currents have made explicit the need to overcome the traditional model of transmission and reception of information, focusing attention on how this information is signified by students. Thus, the model and dynamics of daily classroom life is impacted, causing changes in the action of both teacher and students.In the field of Scienceteachers'training, some contemporary trends have been discussed in an effort to improve the quality of science classes and learning. Among these trends we highlight some assumptions from the "Science, Technology and Society" (STS) movement, such as the organization of teaching based on a theme of the students' context, and the preparation for the exercise of citizenship, enabling them tocritically discussscientific and technological issues (Amaral; Xavier; Maciel, 2009). We also emphasize the discursive interactions in classroom and the importance of considering the different points of view presentin it.

Our experience, coupled with debates in the field of Science teaching, has pointed to the need for rethinking the teacher's work and stimulating studies on theirbasictraining. Harris, Phillips and Penuel (2011), Lehesvuori, Viiri and Rasku-Puttonen (2011) and Smart and Marshall (2013) argue that teacher trainingshould include a reflective process and the opportunity of dealing with other teaching possibilities, which allow them to experience both the theoretical knowledge and the teaching practice in an undissociated way.

In this work we analyze how trainee teachers deal with teaching and learning materials (TLM) produced to facilitate the appropriation of some contemporary trends on teaching. To this end, we observed traineeChemistry teachers giving classes in which this material was used. In order to understand the influence ofcontext-based TLMon the training of Chemistry teachers, we proposed the following research question: Do trainee teachersincorporate the theoretical and methodological assumptions that support the correspondent thematic TLMduring their classes? To answer this question, we examined: the frequency of use of TLMduring classes, the activities proposed by the material that were effectively developed in class, and the discursive interactions established during classes. 


\section{Revisiting the Literature}

Regarding science education, Fourez (2002) comments on young students' lack ofengagement or involvement in imposed processes if they are not convinced that the discussionis interesting for themselves or for society. Although he refers to all fields of knowledge, the author states that this reality is most acute in the curricular components that require scientific abstraction.The discouraging results in the field of Science learning in Latin America, as measured by the Program for International Student Assessment (Pisa), bring implications for teacher training programs. Freitas and Villani (2002) affirm that teacher training courses in the field of Scienceendeavor to form a professional who exercises theoretical reflections. However, research in the field (Quadros et al., 2005; Freitas and Vilani, 2002) warns that theoretical studies have not been sufficient for teachers to incorporate these theories into their practice.Carvalho and Gil-Pérez (2011) highlight the need for the teacher to have a deep scientific knowledge of the discipline that he/she teaches because the lack of this knowledge represents an obstacle to the accomplishment of innovative activities. Nevertheless, they also warn about other formative needs aiming to provoke a rupture with simplistic views on teaching.In this work we report a Chemistry teaching experience adopting a context-based theme -in this casewater during the training of Chemistry teachers in Brazil. This experience was anchored in a context-based teaching material, which isan important assumption of the STS movement. In developing context-based chemical knowledge, we hoped to increase discursive interactions and promote student engagement in class dynamics. We accordingly explore contextbased teaching (a) and research involving the use of TLM in teacher training (b).

\subsection{Context-based Science teaching}

Two main works - The Structure of Scientific Revolutions, by Thomas Kuhn and Silent Spring, by Rachel Carson stimulated discussions about the effects of Science on society and the environment, which originated the STS movement. The belief that technology, produced from scientific development, brings as a consequence the improvement of society's quality of life began to be questioned. Linsingen (2007) states that an important objective of the STS movement was to make the scientific community aware of the social and environmental impacts of technologies: "forming a more realistic image of the social nature of science and technology, as well as of the political role of experts"(Linsingen, 2007, p.8).

Slowly, assumptions of the STS movement became part of the debates around Science teaching. Aikenhead (2005) argues that Science education aims to form citizens capable of acting in a world increasingly permeated by science and technology. To achieve this result it is important that students be able to perceive the many relations among science, technology and society. The teaching of Science based on context has been considered as a good opportunity for students to notice the direct relation between scientific concepts and the social context and develop their interest in science, getting more involved in the classes. In this work, we explore context-based teaching as one of the unquestionable assumptions of the STS movement.

We also consider that themesdiscussed in Chemistry classes should be interesting to students and to Chemistry itself. Being interesting to students is important because it turns them into active participants who will give relevant contributions to the debate; andbeinginteresting toChemistry entails the choice of an adequate subject for explaining the respective scientific concepts.

\subsection{Research involving TLMs and teacher training}

Munakata (2012), when discussing the constitution of a field of research based on textbooks and the fertility of these researches, states that this type of TLM has been examined "as a fundamental element of educational public policies, teaching practices and the constitution and transmission of knowledge and school culture"(p.179). However, research involving textbooks or TLMsare less present in Sciences and Chemistry's literature.

Frison et al. (2009) analyzed the use of textbooks by teachers working in the area of Science in Elementary School. The authorsemphasize the influence of the textbookin the definition of school contents andthe proposition of what will be taught, since many teachers use them as the main instrument to guide the contents they shalldevelop, as well as the sequence they must follow, the learning activities and evaluation of teaching.Nunes-Macedo, Mortimer and Green (2004) analyzed the sociocultural construction of classroom discourse related to the use of textbooks. They found that, in the discursive dynamics, textbooks represent one of the different voices that circulate in classroom. The life and work experience of the analyzed teacheras well asthe school culturewere also parts of the discursive process. The literature offers a significant number of studies investigating how teachers use context-based teaching materials. Ummels, based on materials available in the Netherlands, states that they offer the teacher a coherent idea aboutcontext-based teaching. However, he warns about the need for a support system duringtheimplementation of this material, so that teachers can develop adequate skills so as to adapt and lead context-based classes. In the same line, Vos (2010) investigated the use TLM developed from a context theme in Chemistry classes of aPrimary and Secondary School and whether or not the teachers followeditstheoretical and methodological assumptions. 
According to him, besidesusing a completely new TLMthat is built from a contextual theme, it is necessary to rethink the teacher's role, in a process of learning about "being a teacher". Along the same path, Coenders, Terlouw\& Dijkstra (2008), state thatthe professional development of teachers aiming at educational innovation is complex, and depends onboth innovative teaching materials and well-elaborated and developed continuing education programs.

The TLM used in our research was developed from the theme "Water" and follows the assumption of theSTS movement for teaching Sciences. The activitiespropposedarevaried, with many issues that help the teacher choose among different types of communicative approach (Mortimer and Scott, 2003). According to its authors, the teacher is expected to promote the inclusion of students in classroom dynamics. Following a context-based theme it is expected that students bring significant contributions, includingthemselves in the classroom dynamics. Therefore, it is expected that both the theme and the teacher's discourse favor the inclusion of students in the classroom dynamics. In this sense, the TLM used in this experience can also be regardedas innovative.

\section{Methodology}

\subsection{Teaching Material}

The teaching material used this work was chosen so that trainee teachers could plan and develop a set of classes on the theme "Water" (Quadros, 2016; Quadros and Silva, 2016; Quadros, Silva and Silva, 2016). Figure 1 depicts the organization of the theme Water, which was divided into three modules, accompanied by the main concepts related to each module.

Figure 1: Conceptual diagram of the three TLM modules

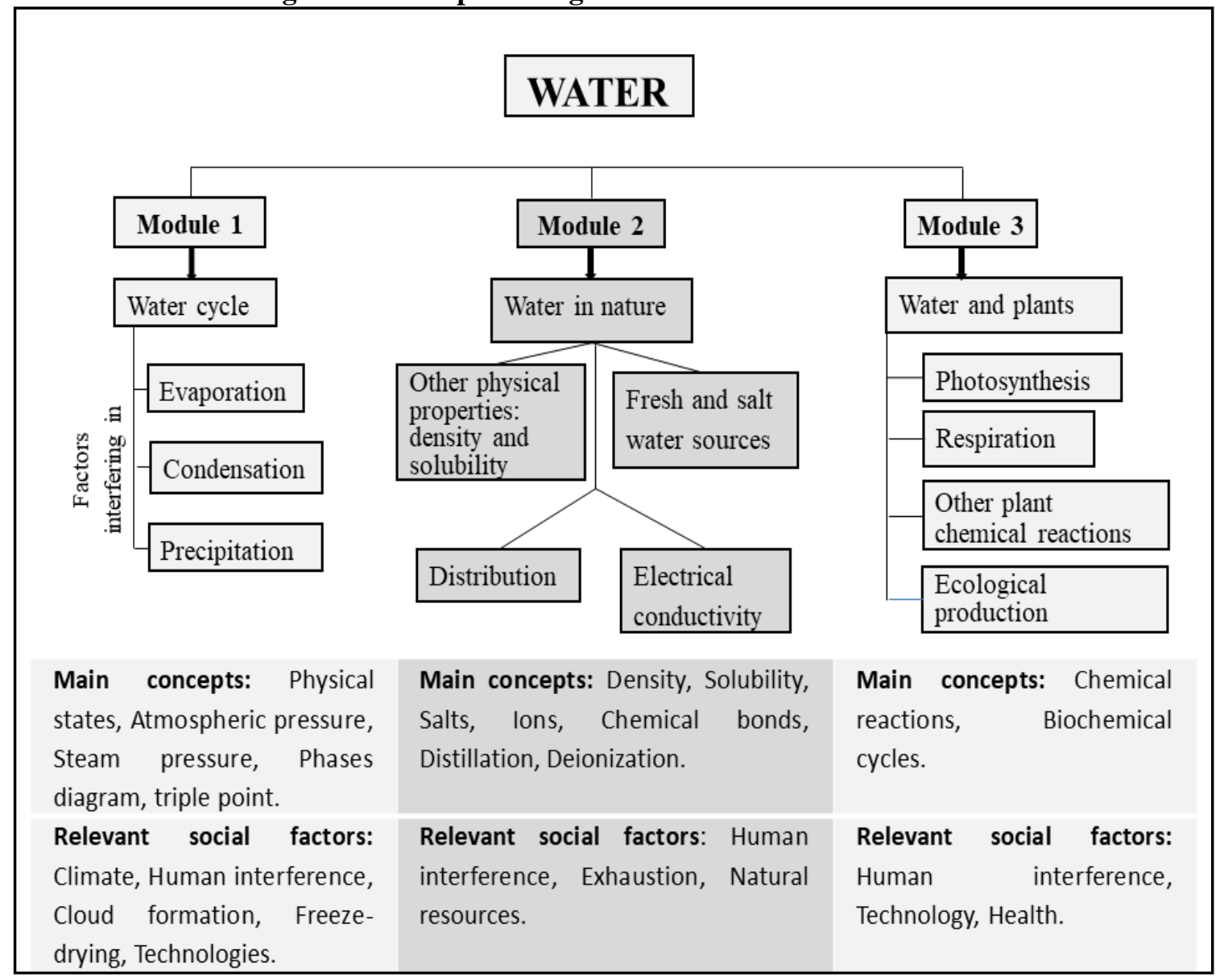

The printed material presents manydiscussing questions, which wereproposedalong all classes. The questions aimed to promote the discussion and evolution of ideas in classroom. Additionally, the TLM was organized with varied activities for the students, such as experiments, reading texts, graphs and explanatory figures.The study began with the construction of a terrarium in a PET bottle, which was cut and filled up with earth, charcoal, water and a small plant, and then was closed and sealed. The construction of this terrarium provided a model for studying the stages of the water cycle - evaporation, condensation and precipitation - and the factors that regulate them. During the discussion, several concepts were presented (see Figure 1). 
The second module deals with other physical properties associated to water (density and solubility), because they facilitate the understanding of interactions of water in the environment and its relation with living beings. The study of the density concept is developed through experiments and that of solubility through the analysis of mineral water labels, leading students to reflect on the difference between fresh and salt, distilled and deionized water and other commonly used water classifications.

The third module is about the relationship between water and plants, always resuming the concepts developed in the two previous modules. Photosynthesis was used to demonstrate in chemical terms how the plant turns light energy into chemical energy. The concept of binding energy was explored to explain both the sequence of semi-reactions that resulted in photosynthesis, and the fact that the plant is able to absorb $\mathrm{CO}_{2}$ (which represents about $0.035 \%$ of the air), but not $\mathrm{N}_{2}$ (about $78 \%$ of the air). After examining the process of photosynthesis, the text turned to the function of glucose in the plant, that is, how the plant uses it to form other important biomolecules for its metabolism.

\subsection{The steps of the work}

This research has qualitative characteristics and, according to Freitas (2002), uses a socio-historical approach to understand the situations investigated in their individual and social aspects, as well as how these aspects inter-relate. We sought to understand the actions of subjects when using the TLM, considering the context of the trainee teachers, therefore assuming some characteristics of case study.The TLM was discussed in weekly meetings involving 12 Chemistry trainee teachers, and three Chemistry teachers of Primary and Secondarypartner schools. Classes were developed in these partner schools, by the trainee teachers. The team meetings were held during and after classes' development in a process of evaluation of participant teacher as well as of the TLM.We included in the research corpus the data from the weekly meetings of the team and the classes developed by the trainee teachers. We collected data by filming both the meetings and the classes, and also using field notes.

As for the data analysis, we watched the videos of the meetings and the classes in full. We selected some episodes of the meetings in which the trainee teachersexpressed their opinions and concerns regarding the use of the material and episodes that occurred during the classes in which it was possible to understand how the trainee teachers used the TLM. Based on Nunes-Macedo, Mortimer and Green (2004), we analyzed the frequency of use of the teaching material during class development. As was done by Vos (2010), our focus was also on the teaching practice of trainee teachers, in order to analyze the appropriation (or not) of the theoretical and methodological assumptions that underlies the material. We also analyzed the choices regarding the activities present in the TLM and the discursive interactions (Mortimer and Scott, 2003) that occurred in class.We transcribed the episodes of interest and for this transcription we used the // symbol when there was a significant pause in speech and the symbol [...]when we suppressed part of the transcribed sequence. We chose to punctuate (exclamation, question mark, and period) the speeches to facilitate understanding, even though we know the punctuation implies some degree of bias. In these transcripts, participants were given fictitious names to remain anonymous.

\section{Results and Discussion}

Results are organized according to the analyzes made, i.e. the frequency of use of printed teaching materials, the choices of the trainee teachers in relation to the pedagogical proposal, their choices regarding the proposed activities and their choices in relation to the discourse in the classroom.

\subsection{The frequency of use of TLM}

The first look at the classes aimed to analyze the frequency with which the trainee teachers recurred to the TLM (printed material) when developing the classes. It is worth mentioning that theyfully participated in the elaboration of the TLM sequence, including the organization of classes and materials to be used, so that all of them were expected to perform the same activities. We considered it as a punctual use when teachers consulted it just to see tables or figures, read texts or suggest exercises. And we regarded it as sequential use, when they used the TLM more frequently, asking the same questions present in the material to start the discussions, and explore explanations in classes, including the order in which they were presented.

Chart 1 shows the frequency with which the trainee teachers used the material. Although twelve people were involved, not all of them worked with the three modules. Five of them developed the three modules, four developed two modules and another three developed only one module. 


\section{Chart 1: Frequency of use of TLM for each training teacher.}

\begin{tabular}{|l|l|l|l|}
\hline Trainee teacher & Module 1 & Module 2 & Module 3 \\
\hline Bárbara & Sequential & Sequential & Sequential \\
\hline Gabriel & Sequential & Sequential & Sequential \\
\hline Carlos & Sequential & Punctual & Sequential \\
\hline Frederico & Punctual & Sequential & Sequential \\
\hline Marcelo & Punctual & Punctual & Sequential \\
\hline Roberta & Punctual & Sequential & --- \\
\hline Gabriela & Punctual & --- & Sequential \\
\hline Paula & Sequential & Sequential & --- \\
\hline Rodrigo & Sequential & Sequential & --- \\
\hline Patricia & --- & Sequential & --- \\
\hline Carla & --- & --- & Punctual \\
\hline Rebeca & --- & --- & Sequential \\
\hline
\end{tabular}

We consider that the sequential use, in which trainee teachers use questions proposed in the TLM to identify previous conceptions and promote discussionsamong students represents an adhesion to the pedagogical proposal contained in the material. We can observed that while little more than half of the trainee teachers used the material sequentially in Module 1, in Module 3 this was quite different. Only Carla, who had not developed the TLM sequence of Modules 1 and 2, made a punctual use ofModule 3.

As soon as Module 1 was developed, we watched the videos of the classes and selected some fragments for sharing with the trainee teachers. We selected a fragment in which the teacher developed his/her class according to the pedagogical proposal and another in which the guidelines were not followed. In these two fragments teachers were asked to observe the participation of students, the contributions they offered to the discourse and how motivated they were, whenever it was possible to observe it. At times these teachers emphasized that students responded better to the class when they were included in the classroom dynamics and their opinions were heard and valued. We believe that this was fundamental to provide their adherence to the pedagogical proposal of the material throughout the classes.

\subsection{Teachers' choices regarding the pedagogical proposal}

The TLM was presented to the trainee teachers as a proposal that aimed to stimulate the students in the classes and develop in them the taste for Science. Thus, teaching in context and the communicative approach were presented to the group as the theoretical inputs used to elaborate the material. We emphasized the presence of questions for discussion with students, as well as the importance of presenting them with explanations of Science and also comparing them with the ones they bring.

As we already mentioned, among those who used TLM in a punctual manner, there was no appropriation of the guidelines discussed in the group meetings before the development of the classes. We selected an example occurred during Teacher Marcelo's practice that is representative of this non-appropriation. To begin the discussion of which factors are related to water evaporation, a simple experiment was proposed consisting of heating the water in a beaker and taking notes of the system temperature every two minutes until it stabilized, in order to discuss its influence on water evaporation. Students were expected to identify that water evaporates at any temperature and not only when it reaches Boiling Temperature, and also to differentiate this concept from the simple physical change of state (which occurs at any temperature). This experiment was to be accompanied by questions for discussion between the teacher and the students and, through this process, the concepts would be developed. However, Teacher Marcelo provided all the explanation about Boiling Temperature, Evaporation and the relationship between Boiling Temperature and Atmospheric Pressure before performing the experiment. This way he did not follow the TLM proposal present in the material.

Examples such as the cited above were common among those who used the material in a punctual manner, since they did not include the concepts as necessary for the understanding of the phenomena studied. When the use was sequential, we observed that the trainee teachers gave more attention to the construction of concepts and the process of significance of knowledge. The preliminary questions were asked and the students' answers were heard and debated. Then, after the experiment was carried out, the answers were resumed and discussed in the light of the results. In these cases, the process of meaning negotiation was part of the classes, confirming the appropriation of theoretical knowledge while developing the classes. 
During one of the class evaluation meetings we discussed how the trainee teachers should use TLM and TeacherCristina, when commenting on context-based Chemistry teaching and the quality of learning materials available in the market brought the following contribution:

Cristina:I think we have to be very careful not to limit the lessons to the contents of a book, for example. We have to keep on understanding, planning, adding and replacing, because if we don't it becomes very similar to textbooks used in some schools. The teacher often gives the class guided by that book and doesn't say anything beyond what is there. And the student sees no use in what the teacher speaks.

This trainee teacher highlighted the authorship of the teacher when she criticized teachers who are "stuck" to textbooks' contents. In fact, this had already been widely discussed when the group commented on teaching practices organized by concepts without a direct link to the social context.After watching film registers of the class, the group resumed the discussion involving other trainee teachers. They used the word "standardize" as can be seen in the following excerpt:

Gabriel:To me the purpose of the material is to standardize the classes. It's to create a pattern from these lessons. I think we have to follow the same line. If everyone does something different, it makes no sense to analyze the class.

Henrique:Each class is composed of different individuals. (...)

Gabriel:But there arecases in which the person "ah I want to teach my way, I will not even look at the script", this also doesn't make sense, for there are people who do this, don't look at the script and want to teach the way they think it must be, establishing then the pattern.

Henrique:But what is the pattern?

Gabriel:It's not a pattern,it's like the material brings a very good explanation abouthow you should question the student. If the person doesn't even try to work it what sense does it make?

Henrique:At this point you're right.

Gabriel:The new material has a step-by-step question guide for each topic. If I don't try to follow it the material is of no use.

Henrique:No! It serves a lot. It serves as a guide.

We can see through this dialogue that the discussion revolved around the role of TLM in the teacher's work. The coordinator intervened, but it was Renata - another trainee teacher- who allowed us to understand the meaning of that discussion.

Coordinator:As authors of the material or part of it we did not have the objective of standardizing.

Paula: To really organize, to guide, right?

Gabriel:But there are people who really deviate from that. It's clear they haven't read the material. Because there are classes so different than those most teachers are giving.

Renata:For example, in the first class there is the terrarium. It makes no sense for you to explain what adsorption is with coal without first explaining why you made the terrarium. Adsorption should come when you discuss the role of coal in the terrarium.

Gabriel: I did not mean to standardize. Ispoke in the direction of the sequence.

At that moment we could understand that the trainee Teachers Gabriel and Renata were referring to a practice they had perceived in Teacher Henrique. The chemical concept had the function of explaining a fact/phenomenon of daily life and Henrique was presenting the concept beforediscussing the fact. An example of this practice has already been described for Teacher Marcelo when he explained the concepts of Boiling Temperature before doing the experiment that would lead to the discussion of this concept.Both Gabriel and Renata did not agree with Henrique's way of working. It is in this sense that they defended the standardization of activities. By using the word "standardization", therefore, they werereferring to the sequence of activities present in the TLM and not to a "stiffening" of the curriculum. This discussion is an indication that trainee teacherswere reflecting on the development of concepts, the planning activity, and especially on how to deal with theoretical and practical knowledge. Teacher autonomy is present, but some in the group agreed with Gabriel and Renata's ideas and seemed to be appropriating some contemporary tendencies of teaching and learning. We believe that the sharing and discussion of class episodes was fundamental so as tostimulate trainee teachersto appropriate, along the classes, the pedagogical proposal present in the TLM.

\subsection{Teachers' choices regarding the proposed activities}

During the classes we perceived that the trainee teachers made choices regarding the content addressed and the resources contained in the TLM, so as to be able to value their interaction with the students most of the time. 
The case of entropy is a very recurrent example. At the beginning of Module 2 - Water in nature - there is an explanation about how solubilization occurs. In the TLMthere are interactions, some questions about energy and entropy to explain solubilization. However, entropy was studied in only one of the classes, and even so quickly, without any deepening. It seems to us that the trainee teachers chose the path that they found most comfortable, the easiest way to explain, even though it would not be the most complete among the options available.In other cases the suppression occurred in the relationship of the contents with technological issues. In the TLM, milk was presented as a typical example of heterogeneous mixture or colloid. As a complementation, UHT and pasteurization technologies were explored. It was suggested to the teachers to carry out this discussion with the students, also debating the advantages and disadvantages of UHT milk as compared to pasteurized milk. The interdisciplinary issues (using concepts from the field of nutrition and biology) and environmental issues (e.g. recycling of packaging) could be part of discussions with students. However, we observed that only one of the teachers proposed this discussion in class.

Along the evaluation meetings, the fact that only one of them dealt with this technology, as well as the motive that led them to not perform certain activities were discussed. Among the justifications presented, the most relevant had to do with the "time" factor, related to developing more content or including the student into the classroom dynamics. There was the guideline that they should listen to students' explanations and points of view and discuss them. In the class evaluation meetings, when we emphasized the fact that contents such as "entropy" and technologies such as "pasteurization/UHT" had not been developed, the discussion turned to planning and its relation to the class. We highlight the intervention of one of the teachers of the school and the comments made by two trainee teachers.

Maurício (school teacher):The classes are prepared for a specific time, so you have a planning for that. Imagine a teacher who can'tgive a book chapter a month, so planning is important. If the content you prepare is for four classes, then you have to account for it in four classes.

Cristina:But then when we consider what the student is talking about, this guides the class a lot and ends up taking part in planning. Listening and problematizing his/her speech takes time, and we will not focus on a single student. There is an entire class participating, so this process is more complex. And it's harder to calculate a time to be able to teach when you can't think about what you will have in classroom.

Joana: (...) you have to have a very clear goal. For everything I'm going to say I know where I want to get to, and I know why I want to get there. There are times when you lose a little of the goal, which is to get to the key concepts. But you have to get there. Your secondary goal is to do this timely.

Cristina:Sometimes in my classes, this (to have no time to give all the planned content) happens, but I've got a feeling (...) that it was in a certain subject in which the student had more difficulty or we had more difficulty in making him/her understand and it took a lot of time. It is more advantageous to ensure that half the content has been understood (...) and not to start dragging the class to complete the content without guaranteeing learning.

The speeches of Joana and Cristina show that the group went through a conflict between including the student in the classroom dynamics and developing all the content. The teacher-supervisor interfered in the discussion, showing a tendency to value content more. Cristina and Joana's statements showed that there was a tension between the time needed to allow student participation and the development of the planned class, but that they were more likely to promote student participation.

Despite the perceived conflicts, the involvement of these trainee teachers with "another" way of teaching, different from the simple transmission of information, and the reflection they made on this experience, while discussing with colleagues, coordinator and teachers of Primary and Secondary School, was very important for the training process. The discussions about what they experienced represent an unparalleled opportunity for reflection on classroom practices based on contemporary trends in teaching and learning. The experience with thematic TLM and the reflection on this practice certainly contributed to the reflection, on the part of that each trainee teachers on the conceptions he/she possesses. In this way they may have built up the knowledge needed to transform this practice. In the speech of each one of them is the desire to continue including students in the dynamics of the class. This desire does not guarantee their full inclusion, but it is a good indication that it may happen when these trainee teachers take up teaching after graduating.

This conflict will probably accompany these trainee teachers when they really start teaching after graduation. Perhaps their own experience, together with research on their practice may help them make more conscious decisions and build a more elaborate conception of what really arekey concepts for the continuity of studies in their field of knowledge.

We also noticed an effort by teachers to include more students into the discussions. Teacher Gabriel used student responses to continue the discourse. At some point Gabriel heard a student's response to the question he had asked. He then asked, "Do you all agree? // Does anyone disagree? As there was no answer he launched a new question: "Did you understand what he said? Did everyone understand?". He clearly invited the students to participate, and simultaneously probed the understanding of those who were not participating. 
When he heard an answer, he chose not to evaluate, but tosocialize it with the other students, maintaining the discussion. Gabrielhad been participating in the project of immersion in teaching for almost a year and,by the analysis of these classes, it seems to us that he will be able, as well as some other participants, to appropriate the dialogic discourse (Mortimer and Scott, 2003) when he is actually teaching.

But even for Gabriel, there was tension about student participation. When this point came to light he made the following comment:

Gabriel: (...)before starting the class, I was scared of not being able to control the students. For example, the student could ask something I wouldn't know how to answer. Something I wasn't prepared for and was not included in the TLM.

Other participants demonstrated the same fear pointed out by Gabriel. The anxiety about facing unusual situations or dealing with the unknown ended up appearing. However, by venturing into an "alternative" mode of teaching, they were gradually becoming more comfortable, and therefore less afraid of the "unknown."

\section{Final considerations}

We analyzed the practice of trainee teachers with the intention of understanding the choices they make when using thematic TLM; they were orientated topositivelyinclude students into the class dynamics, making use of context-based learning anddialogic discourse.

The classes developed in the schools were quite interactive. However, the pedagogical proposal was better appropriated by the trainee teachers who made a sequential use of the TLM. Accordingly, it was this group that most often used dialogic discourse. This is an indication that TLMmay facilitate the appropriation of contemporary teaching tendencies. However, reflection on practice, based ontheoretical knowledge certainly contributed to making these trends more understood and appropriated.

Making choices is inherent tothe teaching practice, especially when it comes to developing contents, and these choices also involve the pedagogical proposal. Choices regarding activities used in the classes and the theoretical and methodological assumptions underlying the TLM showed that, throughout the sequence, the trainee teachers progressively adhered to the pedagogical proposal and faced the conflicts that arose, as they were discussed in the weekly meetings.

When comparing the teaching practice with what was discussed during the meetings of the group, we perceived an attention directed to the development of more interactive classes and an appreciation of the context, placing Chemical Science as a way of explaining this context. The encouragement of students' participation, the development of their reasoning and the stimulation of constructive discussion, even though theymayjeopardize the class timing and the content to be developed, were problematized by the trainee teachers and the resistance to these innovations was significantly reduced.

We understand that the use of TLM provoked discussions and reflections in the trainee teachers, who contributed to construct a more reflective practice. However, the fact that this activity was accompanied by deep reflections guided by the theory was a facilitator for the reflective process to happen. Therefore, the complexity of teacher training, whether initial or continuing, requires multiple, rather than isolated actions.

We have observed that the projects of initiation to teaching have provided the opportunity to practice other "ways" of teaching, beyond the transmission of information. We recommend, however, that these strategies are built within the teacher training courses, so that the trainee teachersmay experience these "other ways" of teaching.Resuming the initial question, it is our belief that the use of the TLM influenced the appropriation of (or at least, the reflection about) some contemporary trends in teaching and learning. However, this is not only a consequence of using TLM, but of a whole reflective process created around it. In this sense, we agree with Ummels (2014) and Coenders, Terlouw and Dijkstra (2008) on the need for a support system for teachers, so they can "venture" in teaching proposals other than the one in which they were trained.

\section{References}

Aikenhead, G. S. (2005). Research into STS science education. Educación Química, 16(3), 384-397.

Amaral, C. L. C.; Xavier, E. S.; Maciel, M. D.(2009). Abordagem das Relações Ciência/Tecnologia/Sociedade nos Conteúdos de Funções Orgânicas em Livros Didáticos de Química do Ensino Médio. Investigações em Ensino de Ciências, 14(1), 101-114.

Carvalho, A. M. P; Gil-Pérez, D. (2011).Formação de professores de Ciências: tendências e inovações (10th ed.).São Paulo:Editora Cortez. 
Coenders, F.; Terlouw, C.; Dijkstra, S. (2008).Assessing teachers' beliefs to facilitate the transition to a new chemistry curriculum: What do the teachers want? Journalof Science TeacherEducation, 19(4), 317-335.

Fourez, G. (2002). Crise no ensino de Ciências? Investigações em ensino de ciências, 8(2), 1-14.

Freitas, M. T. A. (2002). A Abordagem sócio-histórica como orientadora da pesquisa qualitativa. Cadernos de Pesquisa, 116, 21-39.

Freitas, D.; Villani, A. (2002). Formação de professores de Ciências: um desafio sem limites A. Investigações em Ensino de Ciências, 7(3),215-230.

Frison, M. D.; Vianna, J.; Chaves, J. M.; Bernardi, F. N. (2009). Livro Didático como instrumento de apoio para a construção de propostas de ensino de Ciências Naturais. Atas ... VII ENPEC, Florianópolis.Inhttp://www.nutes.ufrj.br/abrapec/ixenpec/atas/resumos/R0545-1.pdfAcessed in 01/07/2019.

Harris, C. J.; Phillips, R. S.; Penuel. W. R. (2012). Examining Teachers' Instructional Moves Aimed at Developing Students' Ideas and Questions in Learner- Centered Science Classrooms. Journal of Science Teacher Education, 23, 769-788.

Lehesvouri, S.; Viiri, J.; Rasku-Puttonen, H. (2011). Introducing dialogic teaching to science student teachers. Journal of Science Teacher Education, 22(8), 705-727.

Linsingen, I. (2007). Perspectiva educacional CTS: aspectos de um campo em consolidação na América Latina. Ciência\&Educação,1( $\mathrm{n}^{\mathrm{o}}$ especial), 1-18.

Mortimer. E. F.; Scott, P. H. (2003). Meaning making in secondary science classroom.Maidenhead: Open University Press/ McGraw Hill Education.

Munakata, K. (2012). O livro didático: alguns temas de pesquisa. Rev. bras. hist. educ., Campinas-SP, 12(3), 179-197.

Nunes-Macedo, M. S. A.; Mortimer, E. F.; Green, J. (2004). A constituição das interações em sala de aula e o uso do livro didático: análise de uma prática de letramento no primeiro ciclo. Rev. Bras. Educ., 25, 18-29.

Quadros, A. L.; Carvalho, D.; Coelho, F. S.; Salviano, L.; Gomes, M. F. P. A.; Mendonça, P. C.; Barbosa, R. K. (2005). Os professores que tivemos e a formação de nossa identidade como docentes: um encontro com nossa memória. Ensaio: Pesquisa em Educação em Ciências, 7(1), 9-18.

Quadros, A. L. (2016). Entendendo o Ciclo da Água(Coleção Temas de Estudo em Química). Contagem-MG: Didática Editora do Brasil Ltda.

Quadros, A. L.; Silva, G. F. (2016). A água na Natureza(Coleção Temas de Estudo em Química). Contagem-MG: Didática Editora do Brasil Ltda.

Quadros, A. L.;Silva, G. F.; Martins, D. C. S. (2016). As plantas e o Ciclo dos Elementos(Coleção Temas de Estudo em Química). Belo Horizonte: Didática Editora do Brasil Ltda.

Smart, Julie B.; Marshall, Jeff C. (2013). Interactions between classroom discourse, teacher questioning, and student cognitive engagement in middle school science. Journal of Science Teacher Education, 24(2), 249-267.

Ummels, M. (2014).Promoting conceptual coherence within biology education based on the concept-context approach.RadboudUniversity Nijmegen. In: https://elbd.sites.uu.nl/wp-content/uploads/sites/ 108/2017/03/Um mels2 014_tbv_ecologie_havo.pdfAccessedin 01/01/2019.

Vos, M. A. J. (2010).Interaction between teachers and teaching materials: on the implementation of contexto based chemistry education. Eindhoven: TechnischeUniversiteit Eindhoven. 